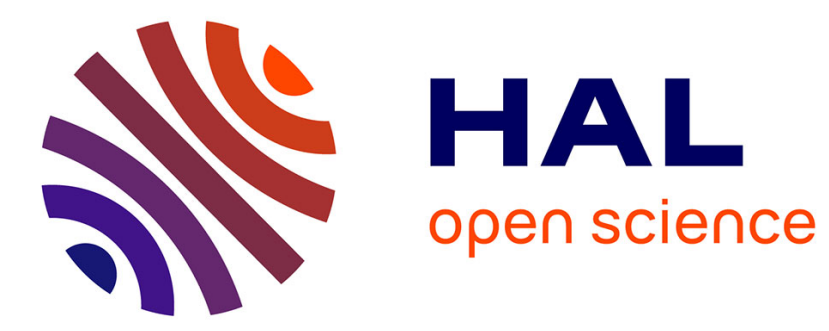

\title{
Hemin-induced suicidal erythrocyte death
}

Sergios Gatidis, Michael Föller, Florian Lang

\section{To cite this version:}

Sergios Gatidis, Michael Föller, Florian Lang. Hemin-induced suicidal erythrocyte death. Annals of Hematology, 2009, 88 (8), pp.721-726. 10.1007/s00277-009-0697-7 . hal-00535028

\section{HAL Id: hal-00535028 \\ https://hal.science/hal-00535028}

Submitted on 11 Nov 2010

HAL is a multi-disciplinary open access archive for the deposit and dissemination of scientific research documents, whether they are published or not. The documents may come from teaching and research institutions in France or abroad, or from public or private research centers.
L'archive ouverte pluridisciplinaire HAL, est destinée au dépôt et à la diffusion de documents scientifiques de niveau recherche, publiés ou non, émanant des établissements d'enseignement et de recherche français ou étrangers, des laboratoires publics ou privés. 


\title{
Hemin-induced suicidal erythrocyte death
}

\author{
Sergios Gatidis • Michael Föller • Florian Lang
}

Received: 29 December 2008 / Accepted: 8 January 2009 /Published online: 29 January 2009

(C) Springer-Verlag 2009

\begin{abstract}
Several diseases, such as malaria, sickle cell disease, and ischemia/reperfusion may cause excessive formation of hemin, which may in turn trigger hemolysis. A variety of drugs and diseases leading to hemolysis triggers suicidal erythrocyte death or eryptosis, i.e., cell membrane scrambling and cell shrinkage. Eryptosis is elicited by increased cytosolic $\mathrm{Ca}^{2+}$ activity and by ceramide. The present study explored whether hemin stimulates eryptosis. Cell membrane scrambling was estimated from annexin Vbinding to phosphatidylserine exposed at the cell surface, cell shrinkage from forward scatter in fluorescence-activated cell sorter analysis, cytosolic $\mathrm{Ca}^{2+}$ activity from Fluo3 fluorescence and ceramide formation from fluorescencelabeled antibody binding. Exposure to hemin $(1-10 \mu \mathrm{M})$ within $48 \mathrm{~h}$ significantly increased annexin V-binding, decreased forward scatter, increased cytosolic $\mathrm{Ca}^{2+}$ activity, and stimulated ceramide formation. In conclusion, hemin stimulates suicidal cell death, which may in turn contribute to the clearance of circulating erythrocytes and thus to anemia.
\end{abstract}

Keywords Phosphatidylserine - Scrambling - Calcium . Cell volume $\cdot$ Eryptosis $\cdot$ Apoptosis

\section{Introduction}

A variety of disorders may lead to formation of hemin, which in turn may drive erythrocytes into cell death $[29,39$, $48,49,59,61,70]$. On the other hand, hemin has been proven useful in the treatment of acute porphyria $[62,63]$. Hemin-induced damage of erythrocytes is considered to be largely due to hemolysis [48, 49, 59, 70]. However, several conditions leading to hemolysis have recently been shown to trigger eryptosis, the suicidal death of erythrocytes [40]. Hallmarks of eryptosis are scrambling of the erythrocyte membrane and cell shrinkage [40]. The cell membrane scrambling leads to exposure of phosphatidylserine at their surface, which is apparent from annexin V-binding of the erythrocytes [40]. Cell shrinkage is apparent from a decrease of forward scatter in fluorescence-activated cell sorter (FACS) analysis [40]. Eryptosis is stimulated by increase in cytosolic $\mathrm{Ca}^{2+}$ activity $[5,11,12,19,41]$. Phosphatidylserine-exposing erythrocytes are engulfed by macrophages and are thus rapidly eliminated from circulating blood [24, 26, 36]. Cytosolic $\mathrm{Ca}^{2+}$ concentration is increased by activation of $\mathrm{Ca}^{2+}$-permeable cation channels $[20,21,32,41]$. The increase in cytosolic $\mathrm{Ca}^{2+}$ activity leads to activation of $\mathrm{Ca}^{2+}$-sensitive $\mathrm{K}^{+}$channels $[9,14]$, which in turn results in exit of $\mathrm{KCl}$ with osmotically obliged water and thus in cell shrinkage [45]. The $\mathrm{Ca}^{2+}$ sensitivity of phospholipid scrambling is increased by ceramide [42].
Department of Physiology, University of Tübingen,

Tübingen, Germany

\section{F. Lang $(\bowtie)$}

Physiologisches Institut, der Universität Tübingen,

Gmelinstr. 5,

72076 Tübingen, Germany

e-mail: florian.lang@uni-tuebingen.de 


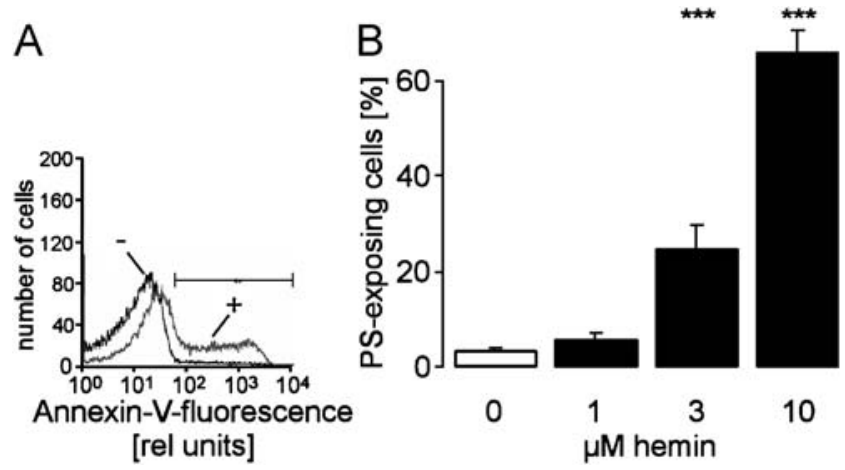

Fig. 1 Effect of hemin on phosphatidylserine exposure of erythrocytes. a Histogram of erythrocyte annexin V-binding in a representative experiment of erythrocytes exposed for $48 \mathrm{~h}$ to Ringer solution without (-, black line) and with $(+$, grey line) $3 \mu \mathrm{M}$ hemin. b Arithmetic means \pm SEM $(n=8)$ of the percentage of phosphatidylserine-exposing erythrocytes following exposure for $48 \mathrm{~h}$ to Ringer solution without (white bar) or with (black bars) hemin. $* * * p<0.001$ indicates significant difference from the respective value without exposure to hemin

The present study explored whether hemin stimulates eryptosis, i.e., cell membrane scrambling and cell shrinkage of erythrocytes, and the underlying mechanism.

\section{Materials and methods}

Erythrocytes, solutions, and chemicals

Leukocyte-depleted erythrocytes were kindly provided by the blood bank of the University of Tübingen. The study is approved by the ethics committee of the University of Tübingen (184/2003V).

Erythrocytes were incubated in vitro at a hematocrit of $0.4 \%$ in Ringer solution containing (in $\mathrm{mM}$ ) $125 \mathrm{NaCl}$, $5 \mathrm{KCl}, 1 \mathrm{MgSO}_{4}, 32 \mathrm{~N}$-2-hydroxyethylpiperazine- $\mathrm{N}-2$ ethanesulfonic acid, 5 glucose, $1 \mathrm{CaCl}_{2} ; \mathrm{pH} 7.4$ at $37^{\circ} \mathrm{C}$ for $48 \mathrm{~h}$. Where indicated, hemin (Sigma, Schnelldorf, Germany) was added at the indicated concentrations.

FACS analysis of annexin V-binding and forward scatter

After incubation under the respective experimental condition, cells were washed in Ringer solution containing $5 \mathrm{mM}$ $\mathrm{CaCl}_{2}$ and then stained with Annexin-V-Fluos (Roche, Mannheim, Germany) in this solution for 20 min under protection from light. In the following, the forward scatter of the cells was determined, and annexin $\mathrm{V}$ fluorescence intensity was measured in FL-1 with an excitation wavelength of $488 \mathrm{~nm}$ and an emission wavelength of $530 \mathrm{~nm}$ on a FACS calibur (BD, Heidelberg, Germany).

Measurement of intracellular $\mathrm{Ca}^{2+}$

After incubation, erythrocytes were washed in Ringer solution and then loaded with Fluo-3/AM (Calbiochem, Bad Soden, Germany) in Ringer solution containing $5 \mathrm{mM} \mathrm{CaCl}_{2}$ and $2 \mu \mathrm{M}$ Fluo-3/AM. The cells were incubated at $37^{\circ} \mathrm{C}$ for $20 \mathrm{~min}$ and washed twice in Ringer solution containing $5 \mathrm{mM} \mathrm{CaCl}_{2}$. The Fluo-3/AM-loaded erythrocytes were resuspended in $200 \mu$ l Ringer. Then, $\mathrm{Ca}^{2+}$-dependent fluorescence intensity was measured in fluorescence channel FL-1 in FACS analysis.

\section{Determination of ceramide formation}

To determine ceramide, a monoclonal antibody-based assay was used. After incubation, cells were stained for $1 \mathrm{~h}$ at $37^{\circ} \mathrm{C}$ with $1 \mu \mathrm{g} / \mathrm{ml}$ anti-ceramide antibody (clone MID 15B4; Alexis, Grünberg, Germany) in phosphate-buffered saline (PBS) containing $0.1 \%$ bovine serum albumin (BSA) at a dilution of 1:5. After two washing steps with PBS-BSA, cells were stained for $30 \mathrm{~min}$ with polyclonal fluoresceinisothiocyanate-conjugated goat anti-mouse $\operatorname{IgG}$ and $\operatorname{IgM}$
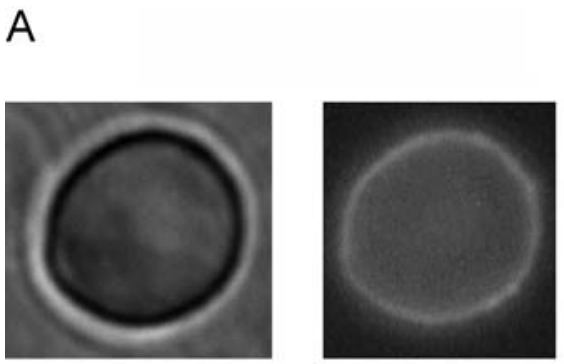

transmission light annexin $\mathrm{V}$ fluorescence
B

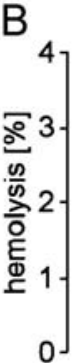

of the percentage of hemolysed erythrocytes following exposure for $48 \mathrm{~h}$ to Ringer solution without (white bar) or with (black bars) hemin. ${ }^{* * *} p<0.001$ indicates significant difference from the respective value without exposure to hemin 
specific antibody (Pharmingen, Hamburg, Germany) diluted 1:50 in PBS-BSA. Unbound secondary antibody was removed by repeated washing with PBS-BSA. Samples were then analyzed by flow cytometric analysis in FL-1.

Measurement of hemolysis

After $48 \mathrm{~h}$ of incubation at $37^{\circ} \mathrm{C}$, the samples were centrifuged ( $3 \mathrm{~min}$ at $400 \mathrm{~g}$, room temperature (RT)), and the supernatants were harvested. As a measure of hemolysis, the hemoglobin $(\mathrm{Hb})$ concentration of the supernatants was determined photometrically at $405 \mathrm{~nm}$. The absorption of the supernatant of erythrocytes lysed in distilled water was defined as $100 \%$ hemolysis. To correct for absorption of hemin contained in the supernatant, the standard curve contained the same amount of hemin.

\section{Statistics}

Data are expressed as arithmetic means \pm SEM, and statistical analysis was made using paired analysis of variance with Tukey's test as post-test, as appropriate. $n$ denotes the number of different erythrocyte specimens studied.

\section{Results}

Cell membrane scrambling during suicidal erythrocyte death or eryptosis was detected by measurement of annexin V-binding reflecting phosphatidylserine exposure. As illustrated in Fig. 1a, b, the percentage of phosphatidylserineexposing erythrocytes was low in the absence of hemin.
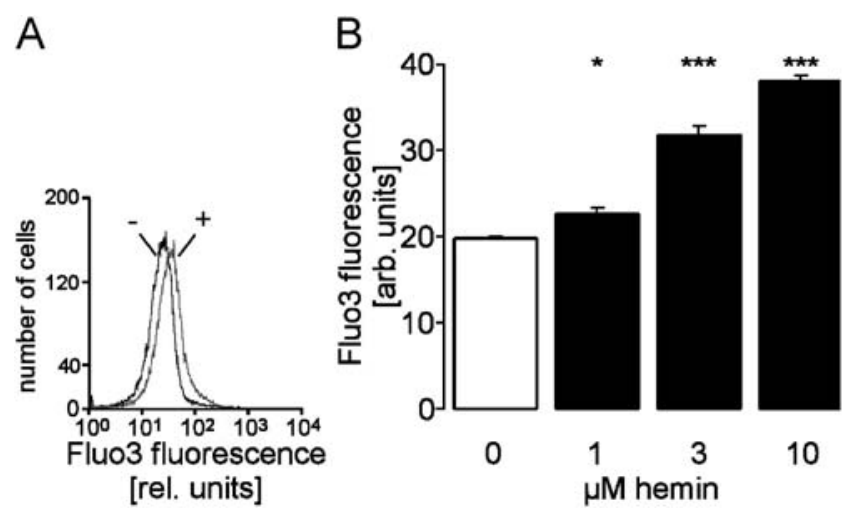

Fig. 4 Effect of hemin on cytosolic $\mathrm{Ca}^{2+}$ concentration in erythrocytes. a Histogram of Fluo3 fluorescence in a representative experiment of erythrocytes exposed for $48 \mathrm{~h}$ to Ringer without (-, black line) and with $(+$, grey line) $10 \mu \mathrm{M}$ hemin $\mathbf{b}$. Arithmetic means $\pm \operatorname{SEM}(n=10)$ of the geo means of Fluo3 fluorescence in erythrocytes exposed for $48 \mathrm{~h}$ to Ringer without (white bar) or with (black bars) hemin. * $p<0.05$, *** $p<$ 0.001 indicate significant difference from the respective value in the absence of hemin

Exposure of erythrocytes for $48 \mathrm{~h}$ to Ringer solution containing hemin (1 to $10 \mu \mathrm{M})$ was followed by a significant increase in erythrocytic annexin V-binding. The integrity of the membrane of the majority of cells was not disrupted at $10 \mu \mathrm{M}$ hemin (Fig. 2a). Thus, hemin only induced hemolysis of a minority of erythrocytes (Fig. 2b).

The stimulation of annexin V-binding was paralleled by a decrease of forward scatter. Exposure of erythrocytes for $48 \mathrm{~h}$ to Ringer solution with hemin $(1$ to $10 \mu \mathrm{M})$ was followed by a significant decrease of erythrocyte forward scatter (Fig. 3).

Further experiments explored whether hemin modifies the cytosolic $\mathrm{Ca}^{2+}$ concentration. To this end, the intracel-
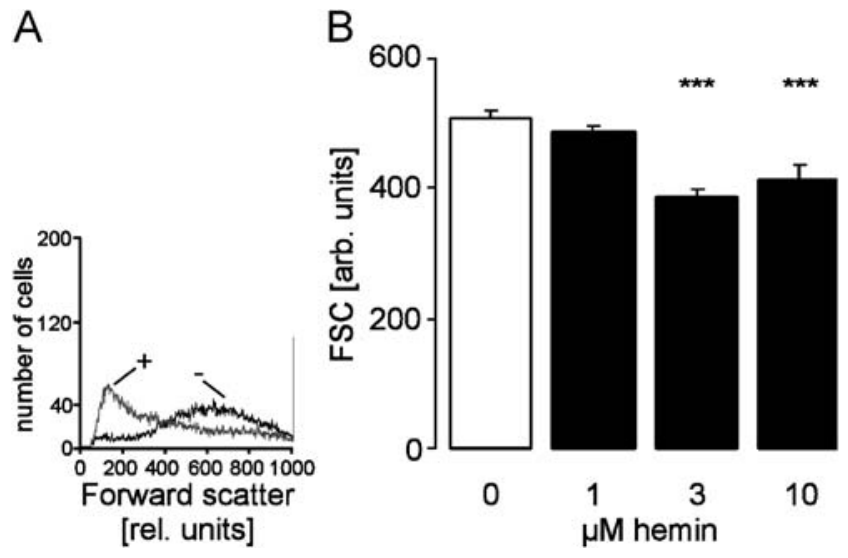

A
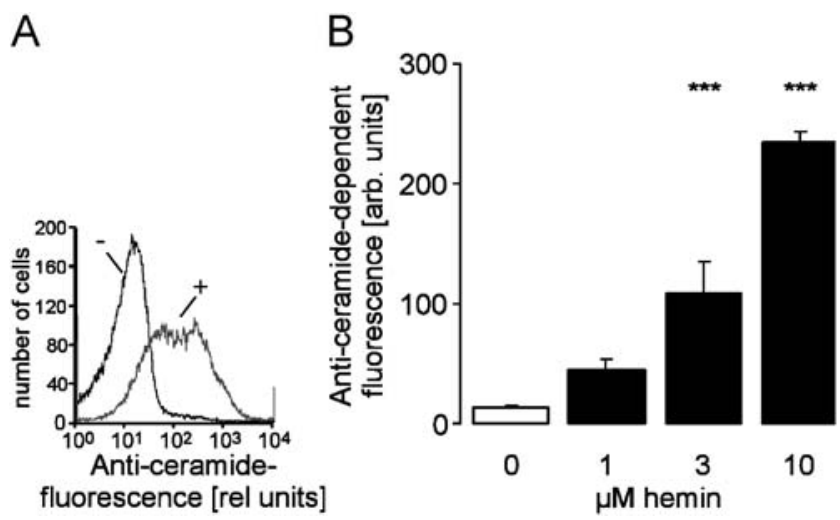

Fig. 3 Effect of hemin on erythrocyte forward scatter. a Original histogram of the forward scatter of erythrocytes following exposure for $48 \mathrm{~h}$ to Ringer solution without (-, black line) and with $(+$, grey line) $3 \mu \mathrm{M}$ hemin. b Arithmetic means $\pm \operatorname{SEM}(n=10)$ of erythrocyte forward scatter following exposure for $48 \mathrm{~h}$ to Ringer solution without (white bar) or with (black bar) hemin. $* * * p<0.001$ indicates significant difference from the respective value without exposure to hemin

Fig. 5 Effect of hemin on ceramide abundance at the erythrocyte membrane. a Histogram of ceramide-dependent fluorescence in a representative experiment of erythrocytes exposed for $48 \mathrm{~h}$ to Ringer without (-, black line $)$ and with $(+$, grey line $) 10 \mu \mathrm{M}$ hemin. b Arithmetic means \pm SEM $(n=7)$ of the ceramide abundance following exposure for $48 \mathrm{~h}$ to Ringer solution without (white bar) or with (black bars) hemin. $* * * p<0.001$ indicates significant difference from the respective value in the absence of hemin 
lular $\mathrm{Ca}^{2+}$ concentration of erythrocytes was determined utilizing Fluo3 fluorescence. As illustrated in Fig. 4, a 48-h incubation of erythrocytes in the presence of 1 to $10 \mu \mathrm{M}$ hemin was followed by a significant increase in Fluo3 fluorescence, indicative of an increase in the cytosolic $\mathrm{Ca}^{2+}$ activity.

Another series of experiments elucidated a possible role of ceramide. As illustrated in Fig. 5, a 48-h exposure of erythrocytes to 1 to $10 \mu \mathrm{M}$ hemin resulted in a significant increase in the ceramide abundance at the erythrocyte surface.

\section{Discussion}

The present study reveals that hemin is a potent stimulator of suicidal erythrocyte death or eryptosis. The exposure of mature human erythrocytes to hemin is followed by a significant increase in phosphatidylserine exposure and a significant decrease of forward scatter, both hallmarks of eryptosis.

A wide variety of clinical disorders is known to stimulate eryptosis, including iron deficiency [36], phosphate depletion [6], hemolytic uremic syndrome [43], sepsis [35], malaria [10, 37, 38], or Wilson's disease [46]. Some of these diseases may cause eryptosis by stimulating the formation of hemin. Furthermore, several eryptosis-triggering xenobiotics and endogeneous substances have been identified, such as cordycepin [50], methylglyoxal [54], amyloid peptides [53], lipopetides [71] retinoic acid [55], paclitaxel [44], amantadine [23], chlorpromazine [1], ciglitazone [58], cyclosporine [56], Bay-5884 [65], curcumin [4], valinomycin [64], listeriolysin [25], aluminum [57], copper [46], bismuth [13], tin [52], cadmium [68], selenium [67], vanadate [27], gold [69], and arsenic [51]. At least in theory, some of those substances may be effective through stimulation of hemin formation.

Eryptotic cells bind to phosphatidylserine receptors on macrophages [22], which engulf and degrade phosphatidylserine-exposing cells [8]. Accordingly, eryptotic cells are rapidly cleared from circulating blood [36], and stimulation of eryptosis leads to anemia, if the accelerated loss of circulating erythrocytes is not matched by a similarly increased formation of new erythrocytes. The latter is apparent from an increase in the reticulocyte number.

Eryptotic cells may further adhere to the vascular wall $[3,17,28,60,72]$ and foster blood clotting [3, 16, 75]. Thus, phosphatidylserine-exposing erythrocytes may compromise the microcirculation. Accordingly, eryptosis has been suggested to participate in the vascular injury of metabolic syndrome [74]. The impact of hemin-induced eryptosis on microcirculation may be compounded by effects of hemin on endothelial cells. Hemin induces oxidative stress in endothelial cells $[2,18,33,34]$. On the one hand, hemin-induced oxidative stress may stimulate apoptosis of nucleated cells [7, 47]; on the other hand, it upregulates heme oxidase $[2,15,18,30]$, which in turn confers resistance to apoptosis $[2,30,66]$. Heme oxidase further stimulates an inflammatory response [73], which may by augmented by Hemin-induced formation of Egr-1 [31].

In conclusion, hemin stimulates suicidal erythrocyte death or eryptosis in vivo. In most patients, the effect may remain below clinical relevance. The possibility needs to be considered, however, that in particularly susceptible patients, the effect may lead to clinically relevant disturbance of microcirculation.

Acknowledgments The authors acknowledge the meticulous preparation of the manuscript by Tanja Loch. This study was supported by the Carl-Zeiss-Stiftung, the Deutsche Forschungsgemeinschaft, Nr. La 315/ and La 315/6-1, the Bundesministerium für Bildung, Wissenschaft, Forschung und Technologie (Center for Interdisciplinary Clinical Research) $01 \mathrm{KS} 9602$ and the Biomed program of the EU (BMH4-CT96-0602).

\section{References}

1. Akel A, Hermle T, Niemoeller OM et al (2006) Stimulation of erythrocyte phosphatidylserine exposure by chlorpromazine. Eur J Pharmacol 532:11-17 doi:10.1016/j.ejphar.2005.12.037

2. Andreadi CK, Howells LM, Atherfold PA et al (2006) Involvement of Nrf2, p38, B-Raf, and nuclear factor-kappaB, but not phosphatidylinositol 3-kinase, in induction of hemeoxygenase-1 by dietary polyphenols. Mol Pharmacol 69:1033-1040

3. Andrews DA, Low PS (1999) Role of red blood cells in thrombosis. Curr Opin Hematol 6:76-82 doi:10.1097/00062752199903000-00004

4. Bentzen PJ, Lang E, Lang F (2007) Curcumin induced suicidal erythrocyte death. Cell Physiol Biochem 19:153-164 doi:10.1159/ 000099203

5. Berg CP, Engels IH, Rothbart A et al (2001) Human mature red blood cells express caspase- 3 and caspase- 8 , but are devoid of mitochondrial regulators of apoptosis. Cell Death Differ 8:11971206 doi:10.1038/sj.cdd.4400905

6. Birka C, Lang PA, Kempe DS et al (2004) Enhanced susceptibility to erythrocyte "apoptosis" following phosphate depletion. Pflugers Arch 448:471-477 doi:10.1007/s00424-004-1289-y

7. Bitzan M, Bickford BB, Foster GH (2004) Verotoxin (shiga toxin) sensitizes renal epithelial cells to increased heme toxicity: possible implications for the hemolytic uremic syndrome. J Am Soc Nephrol 15:2334-2343 doi:10.1097/01.ASN.0000138547. 51867.43

8. Boas FE, Forman L, Beutler E (1998) Phosphatidylserine exposure and red cell viability in red cell aging and in hemolytic anemia. Proc Natl Acad Sci U S A 95:3077-3081 doi:10.1073/ pnas.95.6.3077

9. Bookchin RM, Ortiz OE, Lew VL (1987) Activation of calciumdependent potassium channels in deoxygenated sickled red cells. Prog Clin Biol Res 240:193-200

10. Brand VB, Koka S, Lang C et al (2008) Influence of amitriptyline on eryptosis, parasitemia and survival of Plasmodium berghei- 
infected mice. Cell Physiol Biochem 22:405-412 doi:10.1159/ 000185482

11. Brand VB, Sandu CD, Duranton C et al (2003) Dependence of Plasmodium falciparum in vitro growth on the cation permeability of the human host erythrocyte. Cell Physiol Biochem 13:347-356 doi:10.1159/000075122

12. Bratosin D, Estaquier J, Petit F et al (2001) Programmed cell death in mature erythrocytes: a model for investigating death effector pathways operating in the absence of mitochondria. Cell Death Differ 8:1143-1156 doi:10.1038/sj.cdd.4400946

13. Braun M, Foller M, Gulbins E et al (2009) Eryptosis triggered by bismuth. Biometals doi:10.1007/s10534-008-9180-5

14. Brugnara C, de Franceschi L, Alper SL (1993) Inhibition of Ca(2+)dependent $\mathrm{K}^{+}$transport and cell dehydration in sickle erythrocytes by clotrimazole and other imidazole derivatives. J Clin Invest 92:520-526 doi:10.1172/JCI116597

15. Chen YS, Zhu XX, Zhao XY et al (2008) Hemin, a heme oxygenase-1 inducer, improves aortic endothelial dysfunction in insulin resistant rats. Chin Med J (Engl) 121:241-247

16. Chung SM, Bae ON, Lim KM et al (2007) Lysophosphatidic acid induces thrombogenic activity through phosphatidylserine exposure and procoagulant microvesicle generation in human erythrocytes. Arterioscler Thromb Vasc Biol 27:414-421 doi:10.1161/01. ATV.0000252898.48084.6a

17. Closse C, Dachary-Prigent J, Boisseau MR (1999) Phosphatidylserinerelated adhesion of human erythrocytes to vascular endothelium. Br J Haematol 107:300-302 doi:10.1046/j.1365-2141.1999.01718.x

18. Datla SR, Dusting GJ, Mori TA et al (2007) Induction of heme oxygenase-1 in vivo suppresses NADPH oxidase derived oxidative stress. Hypertension 50:636-642 doi:10.1161/HYPERTEN SIONAHA.107.092296

19. Daugas E, Cande C, Kroemer G (2001) Erythrocytes: death of a mummy. Cell Death Differ 8:1131-1133 doi:10.1038/sj. cdd. 4400953

20. Duranton C, Huber S, Tanneur V et al (2003) Electrophysiological properties of the Plasmodium Falciparum-induced cation conductance of human erythrocytes. Cell Physiol Biochem 13:189-198 doi:10.1159/000072421

21. Duranton C, Huber SM, Lang F (2002) Oxidation induces a Cl(-)dependent cation conductance in human red blood cells. J Physiol 539:847-855 doi:10.1113/jphysiol.2001.013040

22. Fadok VA, Bratton DL, Rose DM et al (2000) A receptor for phosphatidylserine-specific clearance of apoptotic cells. Nature 405:85-90 doi:10.1038/35011084

23. Föller M, Geiger C, Mahmud $\mathrm{H}$ et al (2008) Stimulation of suicidal erythrocyte death by amantadine. Eur J Pharmacol 581:13-18 doi:10.1016/j.ejphar.2007.11.051

24. Foller M, Feil S, Ghoreschi K et al (2008) Anemia and splenomegaly in cGKI-deficient mice. Proc Natl Acad Sci U S A 105:6771-6776 doi:10.1073/pnas.0708940105

25. Foller M, Shumilina E, Lam R et al (2007) Induction of suicidal erythrocyte death by listeriolysin from Listeria monocytogenes. Cell Physiol Biochem 20:1051-1060 doi:10.1159/000110715

26. Foller M, Sopjani M, Koka S et al (2009) Regulation of erythrocyte survival by AMP-activated protein kinase. FASEB J doi:10.1096/fj.08-121772

27. Foller M, Sopjani M, Mahmud H et al (2008) Vanadate-induced suicidal erythrocyte death. Kidney Blood Press Res 31:87-93 doi:10.1159/000119704

28. Gallagher PG, Chang SH, Rettig MP et al (2003) Altered erythrocyte endothelial adherence and membrane phospholipid asymmetry in hereditary hydrocytosis. Blood 101:4625-4627 doi:10.1182/blood-2001-12-0329

29. Ginsburg H (2003) The mysteries of hemoglobin degradation in Plasmodium falciparum-infected erythrocytes. Trends Parasitol 19:198-199 doi:10.1016/S1471-4922(03)00057-6
30. Gonzalez-Michaca L, Farrugia G, Croatt AJ et al (2004) Heme: a determinant of life and death in renal tubular epithelial cells. Am J Physiol Renal Physiol 286:F370-F377 doi:10.1152/ ajprenal.00300.2003

31. Hasan RN, Schafer AI (2008) Hemin upregulates Egr-1 expression in vascular smooth muscle cells via reactive oxygen species ERK1/2-Elk-1 and NF-kappaB. Circ Res 102:42-50 doi:10.1161/ CIRCRESAHA.107.155143

32. Huber SM, Gamper N, Lang F (2001) Chloride conductance and volume-regulatory nonselective cation conductance in human red blood cell ghosts. Pflugers Arch 441:551-558 doi:10.1007/ s004240000456

33. Jeney V, Komodi E, Nagy E et al (2009) Supression of heminmediated oxidation of low-density lipoprotein and subsequent endothelial reactions by hydrogen sulfide $(\mathrm{H}(2) \mathrm{S})$. Free Radic Biol Med doi:10.1016/j.freeradbiomed.2008.11.018

34. Jozkowicz A, Was H, Taha $\mathrm{H}$ et al (2008) 15d-PGJ2 upregulates synthesis of IL-8 in endothelial cells through induction of oxidative stress. Antioxid Redox Signal 10:2035-2046 doi:10.1089/ ars.2008.2032

35. Kempe DS, Akel A, Lang PA et al (2007) Suicidal erythrocyte death in sepsis. J Mol Med 85:269-277 doi:10.1007/s00109-0060123-8

36. Kempe DS, Lang PA, Duranton C et al (2006) Enhanced programmed cell death of iron-deficient erythrocytes. FASEB J 20:368-370

37. Koka S, Lang C, Boini KM et al (2008) Influence of chlorpromazine on eryptosis, parasitemia and survival of Plasmodium berghe infected mice. Cell Physiol Biochem 22:261-268 doi:10.1159/000149804

38. Koka S, Lang C, Niemoeller OM et al (2008) Influence of NO synthase inhibitor L-NAME on parasitemia and survival of Plasmodium berghei infected mice. Cell Physiol Biochem 21:481-488 doi:10.1159/000129641

39. Kumar S, Bandyopadhyay U (2005) Free heme toxicity and its detoxification systems in human. Toxicol Lett 157:175-188 doi:10.1016/j.toxlet.2005.03.004

40. Lang F, Gulbins E, Lerche $\mathrm{H}$ et al (2008) Eryptosis, a window to systemic disease. Cell Physiol Biochem 22:373-380 doi:10.1159/ 000185448

41. Lang KS, Duranton C, Poehlmann H et al (2003) Cation channels trigger apoptotic death of erythrocytes. Cell Death Differ 10 (2):249-256 doi:10.1038/sj.cdd.4401144

42. Lang KS, Myssina S, Brand V et al (2004) Involvement of ceramide in hyperosmotic shock-induced death of erythrocytes. Cell Death Differ 11:231-243 doi:10.1038/sj.cdd.4401311

43. Lang PA, Beringer O, Nicolay JP et al (2006) Suicidal death of erythrocytes in recurrent hemolytic uremic syndrome. J Mol Med 84:378-388 doi:10.1007/s00109-006-0058-0

44. Lang PA, Huober J, Bachmann C et al (2006) Stimulation of erythrocyte phosphatidylserine exposure by paclitaxel. Cell Physiol Biochem 18:151-164 doi:10.1159/000095190

45. Lang PA, Kaiser S, Myssina S et al (2003) Role of $\mathrm{Ca}^{2+}$-activated $\mathrm{K}^{+}$channels in human erythrocyte apoptosis. Am J Physiol Cell Physiol 285:C1553-C1560

46. Lang PA, Schenck M, Nicolay JP et al (2007) Liver cell death and anemia in Wilson disease involve acid sphingomyelinase and ceramide. Nat Med 13:164-170 doi:10.1038/nm1539

47. Levy YS, Streifler JY, Panet H et al (2002) Hemin-induced apoptosis in PC12 and neuroblastoma cells: implications for local neuronal death associated with intracerebral hemorrhage. Neurotox Res 4:609-616 doi:10.1080/10298420210 00045624

48. Li GX, Liu ZQ (2008) The protective effects of ginsenosides on human erythrocytes against hemin-induced hemolysis. Food Chem Toxicol 46:886-892 doi:10.1016/j.fct.2007.10.020 
49. Li SD, Su YD, Li M et al (2006) Hemin-mediated hemolysis in erythrocytes: effects of ascorbic acid and glutathione. Acta Biochim Biophys Sin (Shanghai) 38:63-69 doi:10.1111/j.17457270.2006.00127.x

50. Lui JC, Wong JW, Suen YK et al (2007) Cordycepin induced eryptosis in mouse erythrocytes through a $\mathrm{Ca}^{2+}$-dependent pathway without caspase-3 activation. Arch Toxicol 81:859-865 doi:10.1007/s00204-007-0214-5

51. Mahmud H, Föller M, Lang F (2009) Arsenic-induced suicidal erythrocyte death. Arch Toxicol doi:10.1007/s00204-008-0338-2

52. Nguyen TT, Föller M, Lang F (2009) Tin triggers suicidal death of erythrocytes. J Appl Toxicol 29(1):79-83

53. Nicolay JP, Gatz S, Liebig G et al (2007) Amyloid induced suicidal erythrocyte death. Cell Physiol Biochem 19:175-184 doi: $10.1159 / 000099205$

54. Nicolay JP, Schneider J, Niemoeller OM et al (2006) Stimulation of suicidal erythrocyte death by methylglyoxal. Cell Physiol Biochem 18:223-232 doi:10.1159/000097669

55. Niemoeller OM, Foller M, Lang C et al (2008) Retinoic acid induced suicidal erythrocyte death. Cell Physiol Biochem 21:193202 doi:10.1159/000113761

56. Niemoeller OM, Akel A, Lang PA et al (2006) Induction of eryptosis by cyclosporine. Naunyn Schmiedebergs Arch Pharmacol 374:41-49 doi:10.1007/s00210-006-0099-5

57. Niemoeller OM, Kiedaisch V, Dreischer P et al (2006) Stimulation of eryptosis by aluminium ions. Toxicol Appl Pharmacol 217:168-175 doi:10.1016/j.taap.2006.09.001

58. Niemoeller OM, Mahmud H, Foller M et al (2008) Ciglitazone and 15d-PGJ2 induced suicidal erythrocyte death. Cell Physiol Biochem 22:237-244 doi:10.1159/000149801

59. Omodeo-Sale F, Motti A, Dondorp A et al (2005) Destabilisation and subsequent lysis of human erythrocytes induced by Plasmodium falciparum haem products. Eur J Haematol 74:324-332 doi:10.1111/j.1600-0609.2004.00352.x

60. Pandolfi A, Di Pietro N, Sirolli V et al (2007) Mechanisms of uremic erythrocyte-induced adhesion of human monocytes to cultured endothelial cells. J Cell Physiol 213:699-709 doi:10.1002/jcp.21138

61. Pawluczkowycz AW, Lindorfer MA, Waitumbi JN et al (2007) Hematin promotes complement alternative pathway-mediated deposition of $\mathrm{C} 3$ activation fragments on human erythrocytes: potential implications for the pathogenesis of anemia in malaria. $\mathrm{J}$ Immunol 179:5543-5552
62. Peters HA, Levine R, Cripps D (1998) Acute intermittent porphyria. Neurology 50:1932-1933

63. Pierach CA (1989) Haem and porphyria attacks. Lancet 2:213214 doi:10.1016/S0140-6736(89)90392-9

64. Schneider J, Nicolay JP, Foller M et al (2007) Suicidal erythrocyte death following cellular $\mathrm{K}^{+}$loss. Cell Physiol Biochem 20:35-44

65. Shumilina E, Kiedaisch V, Akkel A et al (2006) Stimulation of suicidal erythrocyte death by lipoxygenase inhibitor Bay-Y5884. Cell Physiol Biochem 18:233-242 doi:10.1159/000097670

66. Silva G, Cunha A, Gregoire IP et al (2006) The antiapoptotic effect of heme oxygenase-1 in endothelial cells involves the degradation of p38 alpha MAPK isoform. J Immunol 177:18941903

67. Sopjani M, Föller M, Gulbins E et al (2008) Suicidal death of erythrocytes due to selenium-compounds. Cell Physiol Biochem 22(5-6):387-394

68. Sopjani M, Foller M, Dreischer P et al (2008) Stimulation of eryptosis by cadmium ions. Cell Physiol Biochem 22:245-252 doi:10.1159/000149802

69. Sopjani M, Foller M, Lang F (2008) Gold stimulates $\mathrm{Ca}^{2+}$ entry into and subsequent suicidal death of erythrocytes. Toxicology 244:271-279 doi:10.1016/j.tox.2007.12.001

70. Wang F, Wang T, Lai J et al (2006) Vitamin E inhibits hemolysis induced by hemin as a membrane stabilizer. Biochem Pharmacol 71:799-805 doi:10.1016/j.bcp.2005.12.002

71. Wang K, Mahmud H, Föller M et al (2008) Lipopeptides in the triggering of erythrocyte cell membrane scrambling. Cell Physiol Biochem 22:381-386 doi:10.1159/000187116

72. Wood BL, Gibson DF, Tait JF (1996) Increased erythrocyte phosphatidylserine exposure in sickle cell disease: flow-cytometric measurement and clinical associations. Blood 88:1873-1880

73. Wright MM, Schopfer FJ, Baker PR et al (2006) Fatty acid transduction of nitric oxide signaling: nitrolinoleic acid potently activates endothelial heme oxygenase 1 expression. Proc Natl Acad Sci USA 103:4299-4304 doi:10.1073/pnas.0506541103

74. Zappulla D (2008) Environmental stress, erythrocyte dysfunctions, inflammation, and the metabolic syndrome: adaptations to $\mathrm{CO} 2$ increases? J Cardiometab Syndr 3:30-34 doi:10.1111/j.15594572.2008.07263.x

75. Zwaal RF, Comfurius P, Bevers EM (2005) Surface exposure of phosphatidylserine in pathological cells. Cell Mol Life Sci 62:971-988 doi:10.1007/s00018-005-4527-3 